\title{
Annual variability of water productivity components in the watershed of Cabeceira Comprida stream, Santa Fé do Sul, Brazil
}

Daniel N. Coaguila, Fernando B. T. Hernandez, Antônio H. de C. Teixeira, Christopher M. Neale, Renato A. M. Franco, et al.

Daniel N. Coaguila, Fernando B. T. Hernandez, Antônio H. de C. Teixeira, Christopher M. Neale, Renato A. M. Franco, Janice F. Leivas, "Annual variability of water productivity components in the watershed of Cabeceira Comprida stream, Santa Fé do Sul, Brazil," Proc. SPIE 9998, Remote Sensing for Agriculture, Ecosystems, and Hydrology XVIII, 99981E (25 October 2016); doi: 10.1117/12.2242007

SPIE. Event: SPIE Remote Sensing, 2016, Edinburgh, United Kingdom 


\title{
Annual variability of water productivity components in the watershed of Cabeceira Comprida stream, Santa Fé do Sul, Brazil
}

\author{
Daniel N. Coaguila*a, ${ }^{*}$, Fernando B. T. Hernandez ${ }^{\mathrm{a}}$, Antônio H. de C. Teixeira ${ }^{\mathrm{c}}$, Christopher M. \\ Neale $^{\mathrm{d}}$, Renato A. M. Franco ${ }^{\mathrm{a}}$, Janice F. Leivas ${ }^{\mathrm{c}}$ \\ ${ }^{a}$ UNESP - Sao Paulo State University, P.O. Box 34, Ilha Solteira, SP, Brazil; ${ }^{b} U N S A$ - National \\ University of Saint Augustine, Ecology Laboratory, Dept. of Biology, Arequipa, Peru; ${ }^{\mathrm{c}}$ Embrapa \\ Satellite Monitoring, Campinas, SP, Brazil; ${ }^{\mathrm{d}}$ Water for Food Global Institute at the University of \\ Nebraska, Lincoln, USA
}

\begin{abstract}
The Cabeceira Comprida stream's watershed, located in Santa Fé do Sul, Brazil, is an agroecosystem with great demand of water for the population and agriculture. During the dry season the water demand exceeds the amount generated by the watershed. It is important to know the dynamics of the water above the ground to improve the water resources management. Ten Landsat 8 images were used combined with Northwestern São Paulo State Weather Network data under different thermohydrological conditions of the year 2014 to quantify actual evapotranspiration $\left(\mathrm{ET}_{\mathrm{a}}\right.$ ), biomass production (BIO) and water productivity (WP) based on $\mathrm{ET}_{\mathrm{a}}$. Using the Simple Algorithm for Retrieving evapotranspiration (SAFER) for calculating $\mathrm{ET}_{\mathrm{a}}$, the Monteith's radiation model was applied for estimating the BIO and for calculation of WP the ratio of $\mathrm{BIO}$ and $\mathrm{ET}_{\mathrm{a}}$. The average pixels for $\mathrm{ET}_{\mathrm{a}}, \mathrm{BIO}$ and WP ranged respectively from 0.38 \pm 0.35 to $2.05 \pm 0.76 \mathrm{~mm} \mathrm{day}^{-1} ; 10.15 \pm 12.19$ to $71.61 \pm 35.54 \mathrm{~kg} \mathrm{ha}^{-1}$ day $^{-1} ; 1.89 \pm 0.76$ to $3.88 \pm 0.86 \mathrm{~kg} \mathrm{~m}^{-3}$. The lower values of $\mathrm{ET}_{\mathrm{a}}\left(0.38 \mathrm{~mm}\right.$ day $^{-1}$; DOY 220), BIO (10.15 $\mathrm{kg} \mathrm{h}^{-1}$ day $^{-1}$; DOY 220) and WP (1.89 kg m $\mathrm{kg}^{-3}$; DOY 204) were obtained in winter, and highest values of $\mathrm{ET}_{\mathrm{a}}\left(2.05 \mathrm{~mm} \mathrm{day}^{-1}\right.$; DOY 364) and BIO (71.64 $\mathrm{kg} \mathrm{ha}^{-1}$ day $^{-1}$; DOY 364) in the summer and WP $\left(3.88 \mathrm{~kg} \mathrm{~m}^{-3}\right.$; DOY 92) in the autumn. The water productivity components can subsidize the monitoring of the agro-ecosystems, being a useful tool to quantify the annual variability of $\mathrm{ET}_{\mathrm{a}}$ and BIO.
\end{abstract}

Keywords: actual evapotranspiration, biomass production, Landsat 8, SAFER

\section{INTRODUCTION}

Water, until recently, seen as an inexhaustible resource, has started to become scarce in several places of the planet. Due to impertinence of unsustainable interventions. These anthropic interventions interfere in the hydrological cycle, causing water scarcity, which, even though is a substance that renews cyclically, is becoming more and more scarce in continental aquatic environments, because the aforementioned impacts have decreased its availability ${ }^{1,2}$.

Since 1970 there has been a worldwide concern about the need to promote environmental recovery and natural resource maintenance. Diffusing the concept of watershed on the world. To face pollution, scarcity and conflicts over water usage, it was necessary to recognize the watershed as an ecological system (which covers all organisms that function together in a determined area), and to understand how natural resources are connected and independent ${ }^{3}$. The watershed is a part of a region $^{2}$ and can be considered as an open geomorphological system, receiving energy from climatic agents and losing it due to runoffs. As an open system, it can be described in independent variable terms, that oscillate around a pattern and finds itself in a dynamic equilibrium ${ }^{1}$.

In Brazil, water is a public asset and has an economical worth. Its management should always provide its multiple uses. As a supply for cities, a source of water for animals, irrigation, among others ${ }^{2}$. Agropecuary, the industry and human consumption are responsible, respectively, for 59,19 and $22 \%$ of water consumption ${ }^{4}$. Measuring this consumption, especially the one of agriculture such as evapotranspiration, in spatial-time scale allows for better water resource management.

*tuheraldo@gmail.com; phone +55 18 3743-1959 - http://www.agr.feis.unesp.br/irrigacao.php

Remote Sensing for Agriculture, Ecosystems, and Hydrology XVIII, edited by

Christopher M. U. Neale, Antonino Maltese, Proc. of SPIE Vol. 9998, 99981E

(C) 2016 SPIE · CCC code: $0277-786 X / 16 / \$ 18 \cdot$ doi: $10.1117 / 12.2242007$ 
In the Northwestern São Paulo State, annual rainfalls are elevated and unevenly temporal distribution, resulting in successive water deficits. This region registers up to eight months of soil water deficit and its characterized as an area exploited by agropecuary ${ }^{6}$, moreover, with a conflicting use of water. What makes that efficient water usage is necessary to assure productivity, making it of extreme importance to evapotranspiration determination, biomass and water productivity, having the possibility of being determined with the use of indirect methods. Based on radiometric measurements obtained from remote sensing.

Remote sensing techniques applied to agriculture enable the generation of time series in regional scale economically, efficiently and operationally, revealing important aspects for agricultural planning ${ }^{7}$, in its management and evaluation of water resources scarcity where water productivity can be improved ${ }^{8}$, being a powerful indicator of agronomic performance and use of water resources.

The Simple Algorithm for Retrieving Evapotranspiration (SAFER) model is based on the ratio of actual $\left(\mathrm{ET}_{\mathrm{a}}\right)$ to the reference $\left(\mathrm{ET}_{0}\right)$ evapotranspiration, and was validated with data from four experiments from the field involving irrigated cultures and natural vegetation in Brazilian semiarid conditions ${ }^{9}$, empirically calibrated for the Northwestern São Paulo State, Brazil ${ }^{10}$ and adjusted to other regions ${ }^{11}$. SAFER is a simple application, not being necessary the classification of vegetation, it doesn't require extreme water conditions or specific radiation physics knowledge. Furthermore, it has the advantage of thermal bands not being required and having the possibility of being applied with meteorological data from different seasons (from conventional to automatic), enabling the evaluation of historical tendencies from water productivity components ${ }^{12}$.

Thus, this study aimed to evaluate the actual evapotranspiration, biomass, and water productivity using the SAFER model by using images from do Landsat 8, in the watershed of Cabeceira Comprida stream, Santa Fé do Sul, SP, Brazil.

\section{MATERIAL AND METHODS}

\subsection{Study area}

The watershed in question is located in the municipality of Santa Fé do Sul, in the extreme northwest of São Paulo State, in the geographic coordinates $20^{\circ} 10^{\prime} 09^{\prime \prime} \mathrm{S}$ and $50^{\circ} 55^{\prime} 05^{\prime \prime} \mathrm{W}$, with $380 \mathrm{~m}$ asl (Figure 1). The climate, according to the Köppen-Geiger ${ }^{13}$ classification is equatorial climate (A), belonging to the equatorial savanna with dry winters, Aw, or humid tropical climate with dry winter. And this region is characterized up to eight months of soil water deficit ${ }^{5}$.

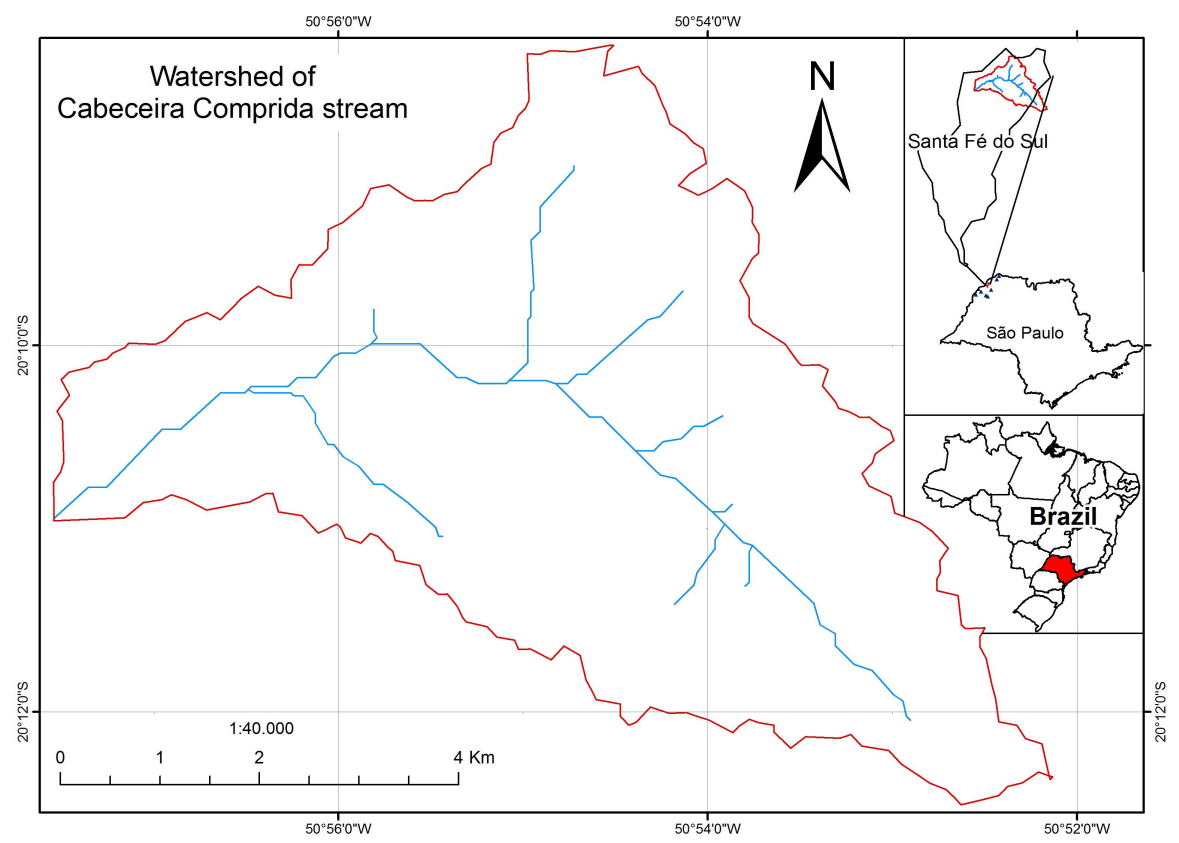

Figure 1. Location of watershed of Cabeceira Comprida stream and the agrometeorological stations. 
With a permanent eucalyptus, banana, rubber, coffee, orange, lemon, mango, tangerine and grape agriculture; cane, manioc, watermelon and corn agriculture; and with support to cattle, horse, swine, goats and sheep breeding, and also gallinaceous ${ }^{6}$.

\subsection{Meteorological variables}

The Northwestern São Paulo State Weather Network (http://clima.feis.unesp.br; Figure 2) was used to obtain the climatic variables: global radiation $\left(\mathrm{R}_{\mathrm{G}}, \mathrm{MJ} \mathrm{m}^{-2} \mathrm{day}^{-1}\right)$, reference evapotranspiration $\left(\mathrm{ET}_{0}, \mathrm{~mm}\right.$ day $\left.^{-1}\right)$ and daily temperature average $\left(\mathrm{T}_{\mathrm{a}},{ }^{\circ} \mathrm{C}\right)$, these variables were specialized by Inverse Distance Weighted (IDW) spatial interpolation contained in the ArcGIS ${ }^{\circ}$ software.

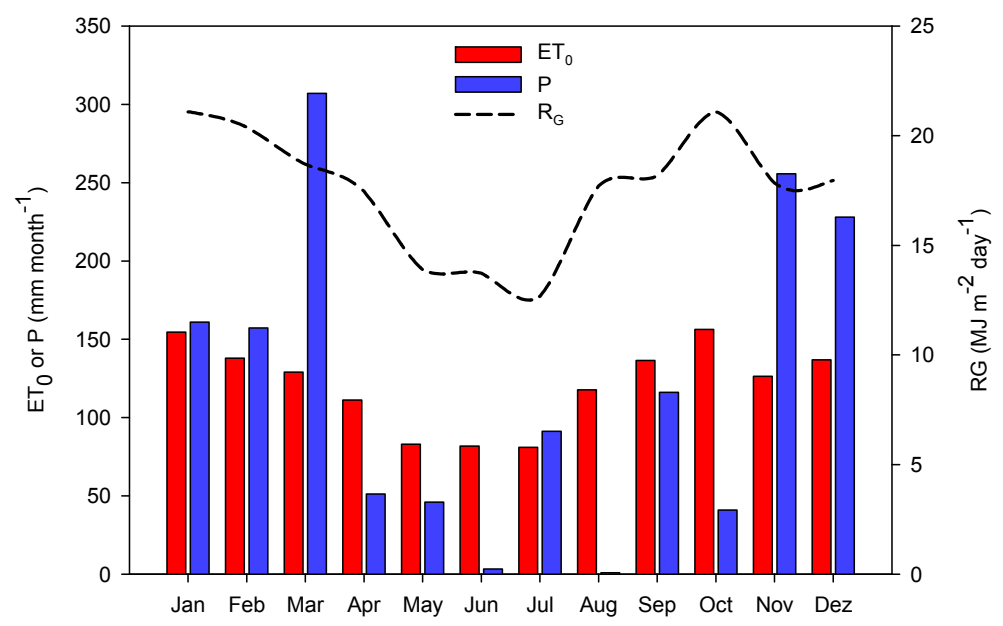

Figure 2. Monthly total values of reference evapotranspiration $\left(\mathrm{ET}_{0}\right)$ and precipitation $(\mathrm{P})$, together with monthly average daily values for global solar radiation $\left(\mathrm{R}_{\mathrm{G}}\right)$ at the weather station, during the year 2014 in the Northwest side of São Paulo State, Brazil.

\subsection{Data collection and pre-processing}

The images to be used were obtained through the USGS (http://earthexplorer.usgs.gov) of the Landsat 8 (OLI and TIRS sensors), with path 222 and row 74, for the period of 2015 (timescale of 16 days). The free images of clouds were used to continue with the next processing steps, using the ArcGIS ${ }^{\circledR} 10.0$ (ArcMap ${ }^{\mathrm{TM}}$ ) from the ESRI for this and the next steps, using the Model Builder function.

The radiometric corrections from the OLI and TIRS sensors according to the Eq. $1^{14}$ for bands $1-7$ and 10-11:

$$
L_{\lambda}=M_{L} Q_{c a l}+A_{L}
$$

where, $L_{\lambda}$ is the spectral radiance in the sensor $\left(\mathrm{W} \mathrm{m}^{-2} \mathrm{sr}^{-1} \mu \mathrm{m}^{-1}\right), \mathrm{M}_{\mathrm{L}}$ is the multiplicative factor (gain), $\mathrm{A}_{\mathrm{L}}$ is the additive factor (offset) and $\mathrm{Q}_{\text {cal }}$ is the quantized calibrated pixel value (DN).

The conversion to reflectance values to each band according the Eq. $2^{15,16}$.

$$
\rho_{\lambda}=\frac{L_{\lambda} \pi}{\mathrm{ESUN}_{\lambda} \cos \theta_{\mathrm{s}} \mathrm{E} 0}
$$

where, $\rho_{\lambda}$ is the planetary reflectance in TOA (no units), ESUN ${ }_{\lambda}$ is the mean exoatmospheric solar irradiance $\left(\mathrm{W} \mathrm{m} \mathrm{m}^{-2} \mu \mathrm{m}^{-1}\right), \theta_{\mathrm{s}}$ is the Solar zenith angle in the moment of acquisition (rad), E0 is the correction of the earth-sun distance (astronomic units).

The wide planetary albedo band in TOA $\left(\alpha_{\mathrm{TOA}}\right)$ was calculated by the Eq. $3^{15,16}$ along the values each band's weight $\left(\omega_{2}\right)$ : 


$$
\alpha_{T O A}=\sum\left(\omega_{\lambda} \rho_{\lambda}\right)
$$

The conversion equation for spectral radiance to sensor's brightness temperature $\left(\mathrm{T}_{\text {bri }}\right)$ is given by Eq. $4^{17}$ :

$$
T_{b r i}=\frac{K 2}{\ln \left(\frac{K 1}{L_{\lambda}}+1\right)}
$$

where, $\mathrm{K} 2$ is the constant of calibration two $(\mathrm{K}) 1321.08$ and 480.89 , respectively, for the band 10 and 11 , $\mathrm{K} 1$ is the constant of calibration one $\left(\mathrm{W} \mathrm{m}^{-2} \mathrm{sr}^{-1} \mu \mathrm{m}^{-1}\right) 774.89$ and 408.89 , respectively, for band 10 and 11 . The average value of bands 10 and 11, was considered $\mathrm{T}_{\text {bri }}$ for Landsat $8^{16}$.

The NDVI is calculated using the ratio between the differentiate of the close infra-red's planetary reflectivity $\left(\rho_{\text {IVP }}\right)$ and of the red $\left(\rho_{\mathrm{V}}\right)$ and the sum of them all:

$$
N D V I=\left(\frac{\rho_{I V p}-\rho_{V}}{\rho_{I V p}+\rho_{V}}\right)
$$

\subsection{Atmospherics corrections}

The data of $\alpha_{\text {TOA }}$ and $T_{\text {bri }}$ were corrected atmospherically to get the values of albedo $\left(\alpha_{0}\right)$ and surface temperature $\left(\mathrm{T}_{0}, \mathrm{~K}\right)$ by using regression analysis ${ }^{18}$ :

$$
\alpha_{0}=a \cdot \alpha_{T O A}+b
$$

where, a and b are regression coefficients 0.6054 and 0.08 , respectively.

$$
T_{0}=a \cdot T_{b r i}+b
$$

where, $\mathrm{a}$ and $\mathrm{b}$ are regression coefficients 1.0694 and -20.173 , respectively.

\subsection{Ratio $\mathbf{E T}_{\mathbf{a}} / \mathbf{E T}_{\mathbf{0}}$}

The $\left(\mathrm{ET}_{\mathrm{a}} / \mathrm{ET}_{0}\right)_{\mathrm{SAFER}}$ ratio, based on satellite images was obtained by the Eq. $8^{9}$ :

$$
\left(\frac{E T_{a}}{E T_{0}}\right)_{S A F E R}=\exp \left[a+b\left(\frac{T_{0}}{\alpha_{0} N D V I}\right)\right]
$$

where, $\mathrm{a}$ and $\mathrm{b}$ are regression coefficients, respectively, 1 and -0.008 for the conditions of Northeastern São Paulo State ${ }^{9,10}$.

\subsection{Water productivity components}

Actual evapotranspiration $\left(\mathrm{ET}_{\mathrm{a}}, \mathrm{mm}\right.$ day $\left.^{-1}\right)$ is obtained by the multiplication of $\mathrm{ET}_{0}$ and $\left(\mathrm{ET}_{\mathrm{a}} / \mathrm{ET}_{0}\right)_{\mathrm{SAFER}}$, obtaining the daily values of $\mathrm{ET}_{\mathrm{a}}$ on a large scale by pixel $^{11}$.

$$
E T_{a}=E T_{0}\left(\frac{E T_{a}}{E T_{0}}\right)_{S A F E R}
$$

where, $\mathrm{ET}_{0}$ is the daily grid of reference evapotranspiration $\left(\mathrm{mm} \mathrm{day}^{-1}\right)$ of the Northeastern São Paulo State Weather Network (http://clima.feis.unesp.br) for each date of image acquisition following the sequential day of year (DOY). 
Eq. 9 doesn't work with bodies of water (NDVI $<0$ ). So the algorithm SAFER uses the equilibrium evapotranspiration concept ${ }^{11}$ under these conditions. The latent flux heat $(\lambda \mathrm{E})$ was obtained by the Eq. 10, applying the conditional function to the values of NDVI, and transforming the energy units to $\mathrm{mm} \mathrm{day}^{-1}$.

$$
\lambda E=\frac{\Delta\left(R_{n}-G\right)}{\Delta+\gamma}
$$

where, $\Delta$ is the slope of the saturation vapour pressure curves $\left(\mathrm{kPa}^{\circ} \mathrm{C}^{-1}\right), \mathrm{R}_{\mathrm{n}}$ is the net radiation $\left(\mathrm{MJ} \mathrm{m}^{-2}\right.$ day $\left.^{-1}\right), \mathrm{G}$ is the soil heat flux $\left(\mathrm{MJ} \mathrm{m}^{-2} \mathrm{day}^{-1}\right), \gamma$ is the psychometric constant $\left(\mathrm{kPa}^{\circ} \mathrm{C}^{-1}\right)$.

The $\mathrm{R}_{\mathrm{n}}$ was obtained by Slob equation ${ }^{19}$ :

$$
R_{n}=\left(1-\alpha_{24}\right) R_{G}-a_{L} \tau_{s w}
$$

where, $\alpha_{24}$ is the surface albedo of 24 hours, $R_{G}$ is the interpolation grid of daily global radiation from agrometeorological stations $\left(\mathrm{W} \mathrm{m}^{-2}\right), \mathrm{a}_{\mathrm{L}}$ is the regression coefficient between the net radiation of long wavelength, atmospheric transmissivity $\left(\tau_{\mathrm{sw}}\right)$ of short waves in a daily scale is calculated by dividing global radiation by TOA radiation $^{20}$.

Eq. 12 is used to calculate 24 hour surface albedo ${ }^{18}$ :

$$
\alpha_{24}=a \cdot \alpha_{0}+b
$$

where, $\mathrm{a}$ and $\mathrm{b}$ are regression coefficients, respectively, 1.023 and 0.0149 .

The $a_{L}$ was spacialized according to the interpolation grid values of $\mathrm{T}_{\mathrm{a}}\left({ }^{\circ} \mathrm{C}\right)$ from agrometeorological stations ${ }^{19}$ :

$$
a_{L}=a \cdot T_{a}+b
$$

where, $a$ and $b$ are regression coefficients, respectively, 6.99 and -39.93 .

The $\mathrm{G}$ was estimated by its relation with net radiation?:

$$
\frac{G}{R_{n}}=a \cdot \exp \left(b \cdot \alpha_{0}\right)
$$

where, $\mathrm{a}$ and $\mathrm{b}$ are regression coefficients, respectively, 3.98 and -31.89 .

Biomass (BIO, $\mathrm{kg} \mathrm{ha}^{-1} \mathrm{day}^{-1}$ ) is obtained by using the Monteith radiation model ${ }^{21}$ :

$$
B I O=\varepsilon_{\max } E_{f} A P A R \cdot 0.864
$$

where, $\varepsilon_{\max }$ is the maximum efficiency of radiation -in the current study $2.5^{22}-\left(\mathrm{g} \mathrm{MJ}^{-1}\right)$ was considered, $\mathrm{E}_{f}$ is the evaporative fraction (no units), APAR is photosynthetically active absorbed radiation $\left(\mathrm{W} \mathrm{m}^{-2}\right), 0.864$ is a unit conversion factor.

The $\mathrm{E}_{f}$, as an indicator of soil humidity, is defined by Eq. $16^{21}$ :

$$
E_{f}=\frac{\lambda E}{R_{n}-G}
$$

where, $\lambda \mathrm{E}$ was obtained by $\mathrm{Eq}, 9$ by transforming $\mathrm{ET}_{\mathrm{a}}$ into energy units.

The APAR was directly approximated from photosynthetically active radiation (PAR), according to Eq. $17^{21}$ :

$$
A P A R=f_{P A R} P A R
$$

where, the $f_{\mathrm{PAR}}$ is estimated from $\mathrm{NDVI}^{18}$ : 


$$
f_{P A R}=a \cdot N D V I+b
$$

where, $\mathrm{a}$ and $\mathrm{b}$ are coefficients 1.257 and -0.161 , respectively ${ }^{22}$.

The PAR on the timescale of 24 hours was obtained by Eq. $19^{23}$ :

$$
P A R=a \cdot R_{G}
$$

where, $\mathrm{a}$ is the regression constant for Brazilian conditions (0.44).

Water productivity $\left(\mathrm{PA}, \mathrm{kg} \mathrm{m}^{-3}\right)$ based on evapotranspiration ${ }^{21}$ was then considered as:

$$
P A=\frac{B I O}{E T_{a}}
$$

\section{RESULTS AND DISCUSSION}

The thermohydrological conditions limit the use of energy in the watershed, the monthly behavior total precipitations (P) and the daily average of $\mathrm{R}_{\mathrm{G}}$ in the year of 2014 are presented in Figure 2. The $\mathrm{R}_{\mathrm{G}}$ represents the main energy resource for $\mathrm{ET}_{\mathrm{a}}$ and during the year of 2014, the $\mathrm{R}_{\mathrm{G}}$ had inferior values in May to July with $13.4 \mathrm{MJ} \mathrm{m}^{-2}$ day $^{-1}$ in mean, by own conditions of winter in the South Hemisphere, meanwhile larger values were registered from January to February and from October to December with $19.7 \mathrm{MJ} \mathrm{m}^{-2}$ day $^{-1}$ in mean, when the Sun is close to the zenith, however, with low cloud covers. A high availability of energy contributes to a strong atmospheric demand. Although, occurring in the month of January the highest $\mathrm{ET}_{0}$, in October the $\mathrm{ET}_{0}$ reached $156.3 \mathrm{~mm} \mathrm{month}^{-1}$, registering the lowest values of $\mathrm{ET}_{0}$ during the months of May to July with $81.9 \mathrm{~mm} \mathrm{month}^{-1}$ in mean. The variations during the year relate to the precipitation data, although these variations aren't too high. Considering natural water input, the $\mathrm{P}$ was the most variable climatic parameter. Only the months of May to July had precipitations inferior to $100 \mathrm{~mm} \mathrm{month}^{-1}$, precipitation being the main part of water balance, as verified in the monthly variation (Figure 2), The biggest rainfall concentrations happened mainly during the months of January to March and November to December. The period with less rainfall was during the months of June to August, confirming what was described for the region's climatic behavior ${ }^{5,13}$.

Figure 3 presents spatial distribution of actual evapotranspiration of the studied watershed, for the year of 2014. The space-time variation was made apparent because of the different thermohydrological conditions, mainly when observing images from DOY 204, 220 and 252 which correspond to the dry season, and images from DOY 28, 76, 92 and 364 to the wet season. During the wet season, $\mathrm{ET}_{\mathrm{a}}$ obtained their maximum values, due to the precipitation effect and high atmospheric demand (Figure 2). Presenting the biggest and lowest $\mathrm{ET}_{\mathrm{a}}$ of 2.05 and $0.38 \mathrm{~mm}$ day ${ }^{-1}$, respectively, coinciding these values with the wet season, where there is a larger availability of energy and precipitation, and with the dry season with lowest levels of energy in the year and practically precipitation absent.

The Cabeceira Comprida stream's watershed has a great environmental and economical importance, being indispensable for either water replenishment for the city of Santa Fé do Sul, generating surplus for sewage dilution generated and is found on an elevated degree of anthropization and the riparian area primarily invaded by hydrophilic and perennial herbaceous plant of genus Typha, classified as "problem species" and an indicator of environmental degradation, in a watershed registered with soil erosion and silting of the riverbed. During all the studied dates, these species took better advantage of the thermohydrological conditions of the wet season and during the dry period they serve themselves from the water supply of the stream and so establish conflicting use of water. Similar results were presented at the Mula stream watershed - SP in dry and wet seasons in the years of 2013 and $2014^{24}$, and in the Tietê river watershed - SP in the dry season of the year of $1996^{25}$, corroborating data from dry season obtained in the current study.

Figure 4 presents time-space distribution of biomass of the Cabeceira Comprida stream's watershed during the year of 2014. Considering the relation between $\mathrm{ET}_{\mathrm{a}}$ and $\mathrm{BIO}$, the space-time variations of the last parameter were also influenced by the thermohydrological conditions of the year of 2014. The biggest areas with biggest BIO values happened during the wet season, as shown in the corresponding images of DOY 28, 76, 92 and 364. During this period there were biomass values superior to $100 \mathrm{~kg} \mathrm{ha}^{-1} \mathrm{day}^{-1}$. The mean values of BIO during winter (DOY 124 and 156) are consequence of rainfall that happened during the wet season, supplying enough water supply in the radicular vegetation 
zone present in the watershed to continue with vegetative development. The smallest values occurred during the dry season, and in the beginning of spring, when it is noted that the gradual increase of BIO due to it recovering itself from water stress the dry season, according the images that correspond to DOY 204, 220 and 252. It is noted that, once more, species installed in the stream during the dry season benefit from the continuous flow of water, from the stream. Biomass values close to the ones presented in the current study were found in Santa Fé do Sul - SP and in three watersheds of the Tietê river - $\mathrm{SP}^{24,25}$.
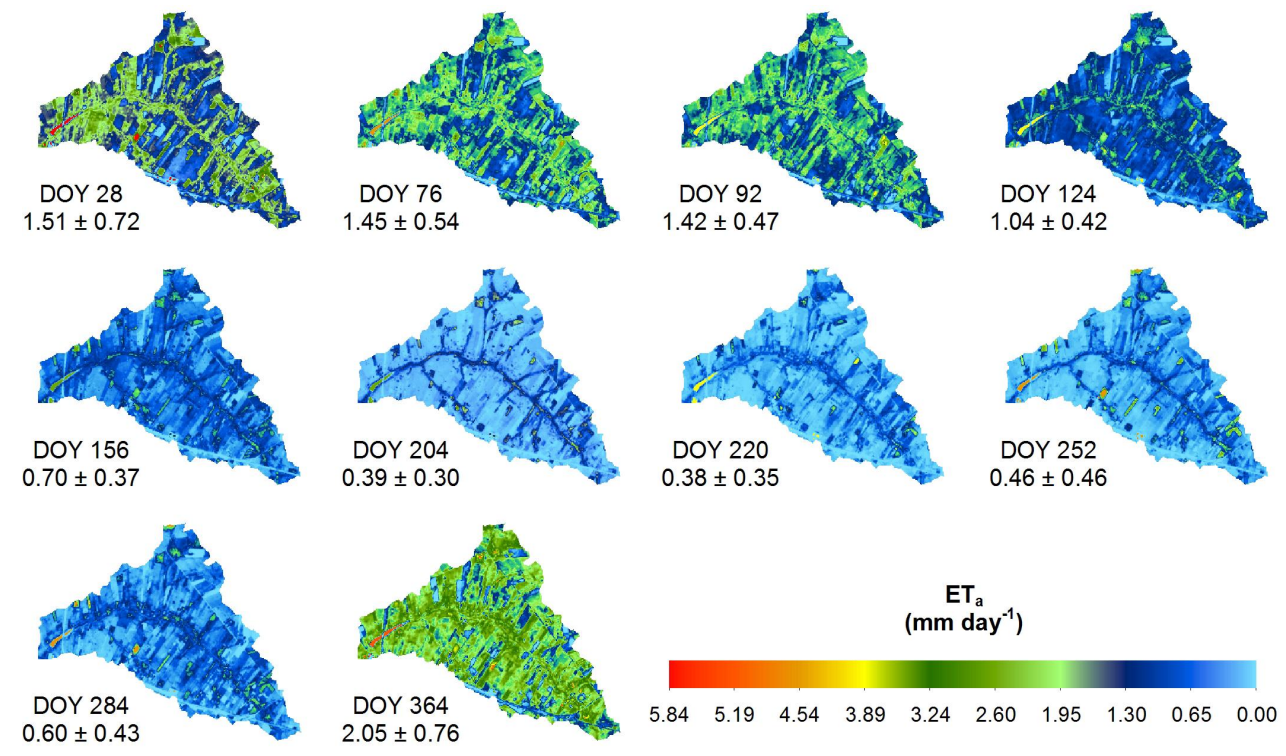

Figure 3. Spatial distribution of actual evapotranspiration at daily time scale in the watershed of Cabeceira Comprida stream, Brazil, during the year 2014. The mean pixel and standard deviation values, and DOY represents day of the year.
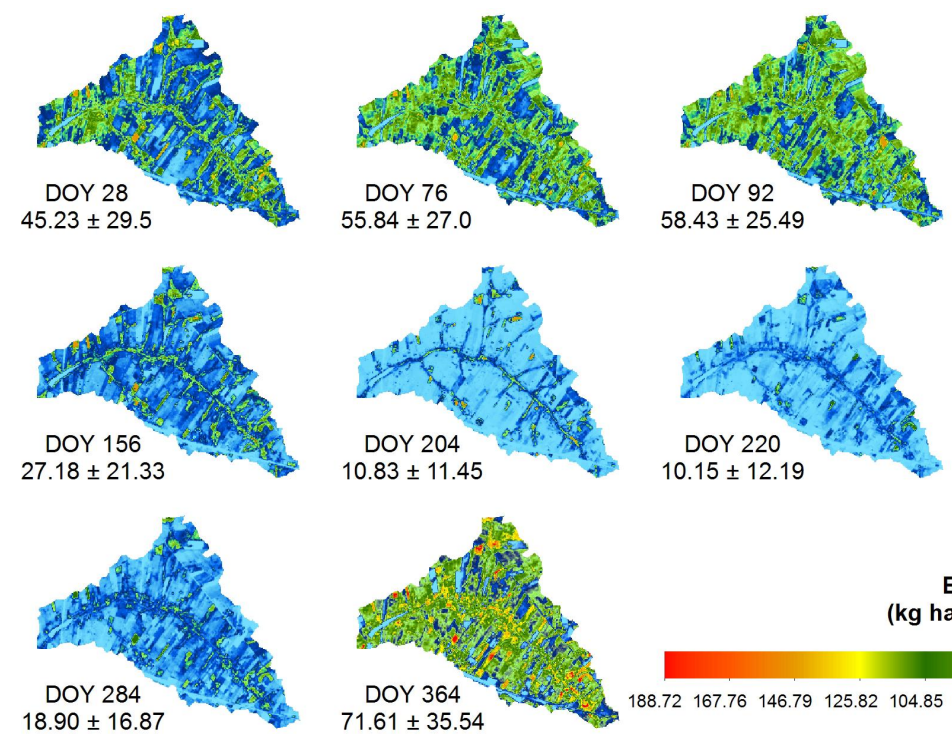

$10.83 \pm 11.45$

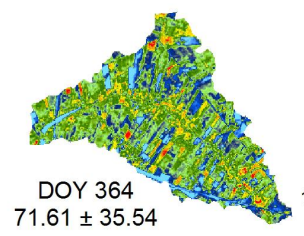

$10.15 \pm 12.19$
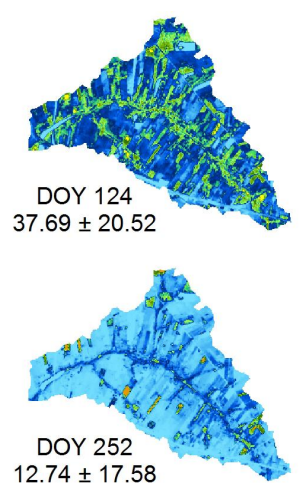

BIO

$\left(\mathrm{kg} \mathrm{ha}^{-1}\right.$ day $\left.^{-1}\right)$

Figure 4. Spatial distribution of biomass at daily time scale in the watershed of Cabeceira Comprida stream, Brazil, during the year 2014. The mean pixel and standard deviation values, and DOY represents day of the year. 
Figure 5 presents the space-time distribution of water productivity of the Cabeceira Comprida stream's watershed, during the year of 2014 in Santa Fé do Sul - SP. Considering that WP is dependent of BIO and ET $\mathrm{a}_{\mathrm{a}}$, which, are dependent of thermohydrological conditions of the watershed and year in study. The biggest mean values of WP occurred, similarly to $\mathrm{ET}_{\mathrm{a}}$ and $\mathrm{BIO}$, during the wet season, where a sufficient quantity of water to be stocked exists and still to be used in the processes of evapotranspiration, and also the sufficient radiation to initiate a high production of biomass, by definition raises the value of WP. These values present themselves in DOY 76, 92, 124, 156 and 364. Meanwhile, the smallest values happened during the dry season, by the season's own conditions, as can be observed in DOY 204, 220 and 252. It can be seen that WP in dry seasons is in its majority, homogeneous, including the stream where invasive species have taken the stream, highlighted in the DOY 220 and 252 (dry season) a slight WP homogeneity, when these species should stand out from the rest of the watershed for possessing a continuous water supply during the whole year. The watershed's heterogeneity ${ }^{6}$ is proven by the elevated values of standard deviation in each date.

On the other hand, in any period of the year - independent of precipitation availability - the riparian zone, which are adjacent areas to the riverbed or thalweg, infested by Typha sp, stand out in water consumption, biomass and water productivity, fulfilling a hydrological function, but without an economical function. The more degraded the watershed, the larger the conflictive use of water and so, studies like this are the base and a proper justification that new studies that detail the participation of each soil coverage in the process of water loss to the atmosphere, being so, SAFER algorithm has shown to be an adequate tool to use to obtain water productivity components.
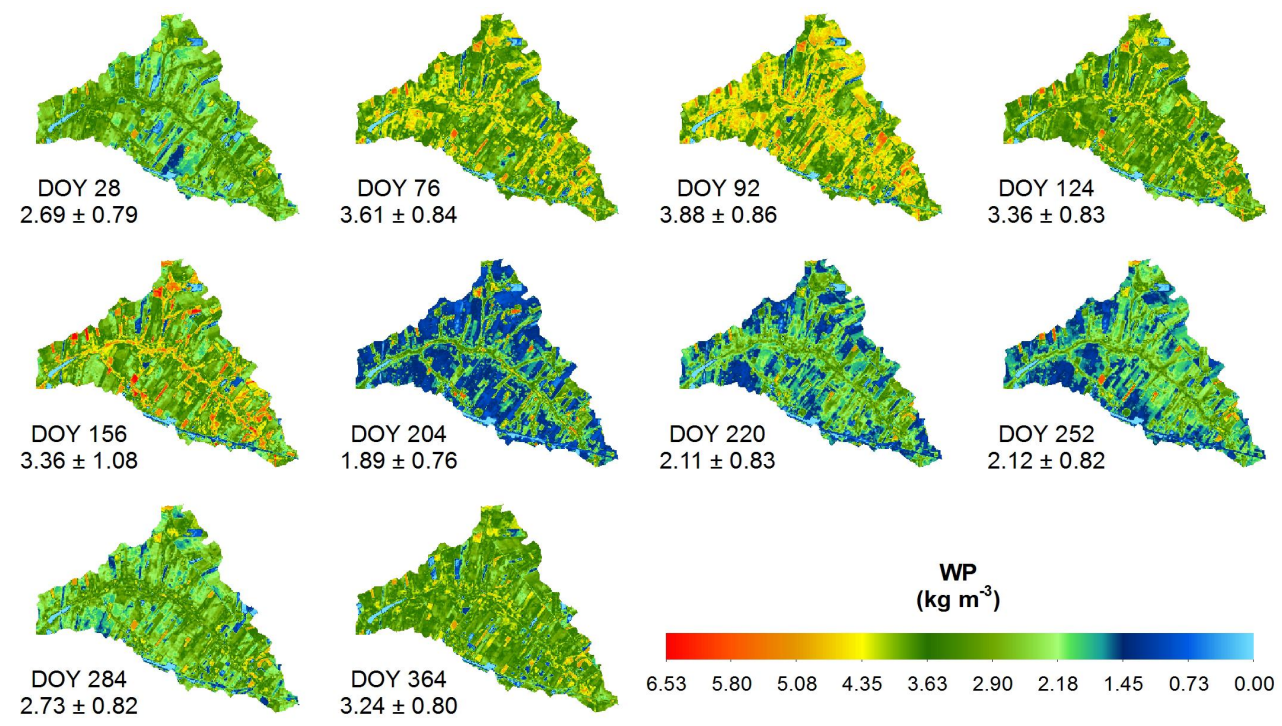

Figure 5. Spatial distribution of water productivity at daily time scale in the watershed of Cabeceira Comprida stream, Brazil, during the year 2014. The mean pixel and standard deviation values, and DOY represents day of the year.

\section{CONCLUSIONS}

The set of data of a network of agrometeorological stations with data obtained from Landsat 8 through remote sensing, has allowed to evaluate water productivity on the Santa do Sul - SP watershed's level, during the period of 2014.

$\mathrm{The}_{\mathrm{ET}}, \mathrm{BIO}$ and WP adjust themselves to the thermohydrological conditions of the study's area, presenting the biggest values during the wet season, as well as the smallest values during the dry season.

Invasive species, fulfill a hydrological function, but without an economical function in Cabeceira Comprida stream's watershed.

The SAFER algorithm, adjusted to the Northwestern São Paulo State, used in this study, possesses enough sensibility to detect the dynamic changes in components of water productivity, contributing to watersheds with fragile ecosystems monitoring. 


\section{ACKNOWLEDGEMENTS}

To FAPESP and CNPq for their financial support, to UNESP's PAEDEx program and to AUIP's 2012 process, for the scholarship.

\section{REFERENCE LINKING}

[1] Lima, W. de P., [Hidrologia florestal aplicada ao manejo de bacias hidrográficas], 2da. ed., Escola Superior de Agricultura "Luiz de Queiroz", Piracicaba (2008).

[2] Machado, A. T. da M., Vieira, D. C., Procópio, J. de C., Polignano, M. V., [Bacia hidrográfica como instrumento pedagógico para a transversalidade], Instituto Guaicuy, Belo Horizonte (2011).

[3] Capra, F., [Alfabetização Ecológica], Cultrix, São Paulo (2007).

[4] Clarke, R.., King, J., [O Atlas da água], Publifolha, São Paulo (2006).

[5] Hernandez, F., de Souza, S., Zocoler, J., Frizzone, J., "Simulação e efeito de veranicos em culturas desenvolvidas na região de Palmeira d'Oeste, estado de São Paulo," Eng. Agrícola 23(1), 21-30, Jaboticabal (2003).

[6] IBGE., "Cidades@”"2016, <http://cod.ibge.gov.br/493> (30 May 2016).

[7] Su, Z., "The Surface Energy Balance System (SEBS) for estimation of turbulent heat fluxes," Hydrol. Earth Syst. Sci. 6(1), 85-100, Göttingen (2002).

[8] Zwart, S. J., Bastiaanssen, W. G. M., "SEBAL for detecting spatial variation of water productivity and scope for improvement in eight irrigated wheat systems," Agric. Water Manag. 89(3), 287-296, Amsterdam (2007).

[9] Teixeira, A. H. de C., "Determining Regional Actual Evapotranspiration of Irrigated Crops and Natural Vegetation in the São Francisco River Basin (Brazil) Using Remote Sensing and Penman-Monteith Equation,” Remote Sensing 2(5), 1287-1319, Basel (2010).

[10] Hernandez, F. B. T., Neale, C. M. U., Teixeira, A. H. de C., Taghvaeian, S., "Determining large scale actual evapotranspiration using agro-meteorological and remote sensing data in the northwest of São Paulo state, Brazil," Acta Hortic.(1038), P. Braun, Ed., 263-270, ISHS (2014).

[11] Teixeira, A. H. de C., Padovani, C. R., Andrade, R. G., Leivas, J. F., Victoria, D. de C., Galdino, S., "Use of MODIS images to quantify the radiation and energy balances in the Brazilian Pantanal," Remote Sensing 7(11), 14597-14619, Basel (2015).

[12] Teixeira, A. H. de C., Hernandez, F. B. T., Lopes, H. L., Scherer-Warren, M., Bassoi, L. H., [Modelagem espaçotemporal dos componentes dos balanços de energia e de água no Semiárido brasileiro], 1ra ed., Embrapa Monitoramento por Satélite, Campinas (2013).

[13] Kottek, M., Grieser, J., Beck, C., Rudolf, B., Rubel, F., "World map of the Köppen-Geiger climate classification updated," Meteorol. Zeitschrift 15(3), 259-263, Berlin (2006).

[14] Vanhellemont, Q., Ruddick, K., "Turbid wakes associated with offshore wind turbines observed with Landsat 8," Remote Sens. Environ. 145, 105-115, New York (2014).

[15] Allen, R. G., Tasumi, M., Trezza, R., Waters, R., Bastiaanssen, W., [SEBAL (Surface Energy Balance Algorithms for Land) - Advanced Training and User's Manual], Idaho Implementation, Idaho (2002).

[16] Teixeira, A. H. de C., Leivas, J. F., Andrade, R. G., Hernandez, F. B. T., Franco, R. A. M., "Modelling radiation and energy balances with Landsat 8 images under different thermohydrological conditions in the Brazilian semi-arid region," Remote Sens. Agric. Ecosyst. Hydrol. XVII(December), C. M. U. Neale and A. Maltese, Eds., 96370U - 1-96370U - 14, Proc. of SPIE (2015).

[17] Chander, G., Markham, B. L., Helder, D. L., "Summary of current radiometric calibration coefficients for Landsat MSS, TM, ETM+, and EO-1 ALI sensors," Remote Sens. Environ. 13(5), 893-903, New York (2009).

[18] Teixeira, A. H. de C., Bastiaanssen, W. G. M., Ahmad, M. D., Bos, M. G., "Reviewing SEBAL input parameters for assessing evapotranspiration and water productivity for the Low-Middle São Francisco River basin, Brazil. Part B: Application to the regional scale," Agric. For. Meteorol. 149, 477-490, Amsterdam (2009).

[19] Teixeira, A. H. de C., Bastiaanssen, W. G. M., Ahmad, M. D., Moura, M. S. B., Bos, M. G., "Analysis of energy fluxes and vegetation-atmosphere parameters in irrigated and natural ecosystems of semi-arid Brazil," J. Hydrol. 362(1-2), 110-127, Amsterdam (2008). 
[20] Bruin, H. A. R. de, "Evaporation and weather," [Proceedings and Information: TNO Committee on Hydrological Sciences], J. C. Hooghart, Ed., CHO, Ede, Netherlands, 5-31 (1987).

[21] Teixeira, A. H. de C., Leivas, J. F., Andrade, R. G., Hernandez, F. B. T., "Water productivity assesments with Landsat 8 images in the Nilo Coelho irrigation scheme," Irrig. Botucatu, 1-10, Botucatu (2015).

[22] Bastiaanssen, W. G. M., Ali, S., "A new crop yield forecasting model based on satellite measurements applied across the Indus Basin, Pakistan," Agric. Ecosyst. Environ. 94(3), 321-340, Amsterdam (2003).

[23] Teixeira, A. H. de C., [Water productivity assessments from field to large scale. A case study in the Brazilian semi-arid region], LAP Lambert Academic Publishing, Saarbrücken, Germany (2009).

[24] Coaguila, D., Hernandez, F. B. T., Teixeira, A. H. de C., "Estacionalidade da evapotranspiração e produtividade da água na microbacia do córrego da Mula em Santa Fé do Sul - SP,” Rev. Bras. Agric. Irrig. 9(4), 232-238, Fortaleza (2015).

[25] Franco, R. A. M., Hernandez, F. B. T., Teixeira, A. H. de C., "Water productivity of different land uses in watersheds assessed from satellite imagery Landsat 5 Thematic Mapper," Proc. SPIE 9239, C. M. U. Neale and A. Maltese, Eds., 92392E - 1-92392E - 7 (2014). 